WIAS Discussion Paper No.2008-001

\title{
Does Corporate Culture Matter?
}

\section{Evidence from Japan}

April 23, 2008

Shinichi Hirota (Waseda University/NIFS)

Katsuyuki Kubo (Waseda University/NIFS)

Hideaki Miyajima (Waseda University/NIFS/WIAS)

Waseda Institute for Advanced Study (WIAS)

1-6-1 Nishiwaseda, Shinjuku-ku, Tokyo 169-8050, Japan

Tel: +81-3-5286-2460 ; Fax: +81-3-5286-2470 


\title{
Does Corporate Culture Matter?
}

\section{Evidence from Japan}

\begin{abstract}
Corporate culture does matter. Using data on mission statements of large Japanese firms, we show that corporate culture has a significant impact on corporate policies that determine employment, board, and financial structures. We provide evidence that strong-culture firms are more likely to retain incumbent employees, promote managers from within firms, and have less debt and a higher percentage of interlocking shareholdings than weak-culture firms. This evidence suggests that strong-culture firms consider their culture to be organizational capital and adopt policies to preserve it. We also confirm that culture and its embedding contribute to better corporate performance. We find these culture effects to be considerable in magnitude and at least as large as those of other factors, and assert that the role of culture must be taken into account in order to understand corporate policies and performance.
\end{abstract}

Keywords: corporate culture, corporate policies, organizational capital, corporate performance, mission statement

JEL classification: G32, G34, J24, M14, M51

Corresponding author. Tel.: +81-3-5286-2088

E-mail address: shirota@waseda.jp 


\section{Introduction}

Recently, corporate culture has been acknowledged to be a significant determinant of organizational behavior and performance. The press and the mass media often make references to a specific corporation's culture, such as the HP Philosophy, the IBM Way, and 3M Value, and attribute each company's competitive advantage to its culture. Furthermore, several books and various case studies have focused on corporate culture to explain how it works, how it changes and evolves, and how it influences behavior and corporate performance (e.g., Deal and Kennedy, 1982: Schein, 1985: Collins and Poras, 1994).

In spite of the popular attention paid to corporate culture, however, very few quantitative studies have been conducted to establish its importance. The scarcity of quantitative evidence can be attributed to the fact that corporate cultures have tacit, ambiguous, and unobservable aspects, which are usually hard to measure using publicly available information, and thus pose an obstacle to quantitative analysis. There are a few exceptional works such as Denison (1984), Gordon and DiTomaso (1992), Kotter and Heskett (1992), and Sorensen (2002) which report that corporate culture and cultural strength are associated with superior performance. However, these previous studies focused almost exclusively on culture's impact on performance. Needless to say, ascertaining the statistically significant performance effects of culture, and determining whether a particular culture enhances or harms performance are not easy tasks.

In this paper, we examine the significance of corporate culture by focusing on its impact on corporate policies. Considering corporate culture to be organizational capital, we set forth the hypothesis that culture shapes corporate policies that determine employment, board and financial structures. More specifically, we hypothesize that 
strong-culture firms are more likely to retain incumbent employees, promote managers from within firms, and reduce the probability of default and hostile takeovers than weak-culture firms.

One of the distinguishing features of this paper is the use of the mission statement as a proxy for corporate culture. It is true that it is not always clear whether the norms and values of the mission statement have actually been adopted and implemented by the corporation. But the advantage of using the mission statement is that it puts into writing the norms and values that corporations require their employees to share and adopt. We also examine how the mission statement is embedded among employees in order to identify the strength of a particular corporate culture.

Our study is conducted on large-sized Japanese firms for the period from 1986 to 2000. The corporate culture of Japanese firms has attracted much attention since the 1980s, when it was considered to be a source of their competitive advantage in global markets (Ouchi, 1981: Pascale and Athos, 1981). Despite this attention, however, little quantitative evidence on the importance of the corporate culture of Japanese firms has been collected.

Testing for the period when Japanese firms were buffeted by unexpectedly large business fluctuations arising from the burgeoning and collapse of the bubble, the subsequent long-term recession, and the banking crisis of 1997, our empirical results show that corporate culture and its strength significantly affect corporate policies. Through business upturns and downturns, strong-culture firms are more likely to adopt policies that encourage long-term employment, and to have more managers promoted from within the firm than weak-culture firms. Strong-culture firms are also more likely to have less debt, and a high percentage of interlocking shareholdings than weak-culture firms. All of our empirical results show that corporate culture does matter 
for the policy choices of Japanese companies. Interestingly, in spite of policy choices which are frequently regarded to be impediments to corporate performance in the finance literature, ${ }^{1}$ firms with strong cultures performed relatively better throughout this period.

This paper is organized as follows. Section 2 surveys the field of corporate culture studies and presents our general observations on various approaches to the study of corporate culture. Section 3 presents hypotheses on the effect of culture on corporate policies. Section 4 explains our sample, data, measures of corporate culture, and regression equations. Section 5 presents our empirical results. Section 6 summarizes the results and discusses their implications.

\section{Background}

\subsection{Significance of Corporate Culture: Previous Studies}

It has long been assumed that corporate culture can make a significant contribution to corporate performance. Corporate culture, which is sometimes referred to as organizational culture, can be defined as "a set of values, beliefs, and norms of behavior shared by its (a firm’s) members that influences employee preferences and behaviors” (Besanko et al., 2007, p.550). Researchers have claimed that culture can be a major source of efficiency in organizations and improve corporate performance (e.g. Kotter and Heskett, 1992: Cremer, 1993: Hermalin, 2001: Besanko et al., 2007). They have argued that the performance benefits of corporate culture derive from three effects. Culture can have a goal-setting effect when it specifies the goals of the firm and makes

\footnotetext{
${ }^{1}$ For example, lower debts levels have been associated with the free cash flow problem and interlocking shareholding has been linked to insider control problems (Jensen,1986: Miyajima and Kuroki, 2007).
} 
it easier for employees to make daily decisions. Culture has a coordination effect when it reduces communication costs and facilitates coordination among employees. And culture has a motivation effect when employees become more highly motivated as a result of embracing the company’s culture.

The view that corporate culture has a significant influence on performance is widely held in academia and by the media, but the empirical evidence that can be marshaled to support this view is scant. Most researchers have relied on anecdotes or case studies and therefore have produced studies of little quantitative value. The difficulty of directly measuring the impact and strength of corporate culture has posed obstacles to the conduct of quantitative research in this area. The exceptions are Denison (1984), Gordon and DiTomaso (1992), Kotter and Heskett (1992), and Sorensen (2002), who report that a strong corporate culture is associated with superior performance. However, it is difficult to determine a positive correlation between culture and performance because some firms may have nonadaptive or defective cultures that actually harm performance (Kotter and Heskett, 1992: Hodgeson, 1996).

\subsection{Corporate Culture and Corporate Policies}

As shown above, previous quantitative studies on corporate culture have focused almost exclusively on the association between culture and performance. Few studies have spotlighted the effect of culture on a firm's policies and strategies. ${ }^{2}$

\footnotetext{
2 The exception is Cronqvist, Low, and Nilsson's (2007) econometric study, which we came across in the course of revising our paper. While their study has a title which is similar to ours and presents evidence that corporate culture significantly affects a firm's policies, as does our paper, it adopts an approach which is significantly different from ours. They argue that firms with similar cultures exhibit similar corporate policies, and seek to prove their argument by showing the commonality of investment and financial policies between spinoff and parent firms. By contrast, we argue that firms with their own corporate culture adopt policies that preserve the culture as organizational capital, and attempt to show that a firm's cultural strength affects employment, board, and financial structures.
} 
In this paper, we examine the significance of corporate culture, focusing on corporate policies affecting employment, board and financial structures. We hypothesize that culture, which can be viewed as firm-specific capital, affects these policies. Firm-specific capital, which is also called organizational capital, is an asset specific to and embedded into an organization, and includes employees' skills and know-how that have use only within a particular firm, information on each employee's aptitude for a particular job, experience in coordinating diverse production technologies, and the goodwill of customers. Firm-specific capital usually has the following characteristics: it is a productive resource unique to a particular firm and not transferable to other firms; it ceases to be productive when the firm is dissolved; and it is accumulated through investment (Prescott and Visscher, 1980: Iwai, 2002: Lev and Radhakrishnan, 2004). Corporate culture has these three characteristics of firm-specific capital; it is hard to imitate; it disappears with the demise of an organization; and it is accumulated through the learning and education of employees.

If we regard corporate culture to be firm-specific capital and valuable in enhancing performance, we can assume that strong-culture firms have an incentive to maintain and utilize the culture rather than build a new (different) culture. Preserving corporate culture and sustaining the organization in which the culture is embedded can increase the firm's value via two effects. First, it raises current performance. The firm takes advantage of its accumulated culture to operate efficiently. Second, it improves future performance. Observing that the culture and the organization continue to exist, the employees are encouraged to make culture-specific investments which facilitate further accumulation of organizational capital.

Therefore, strong-culture firms can be assumed to adopt policies that preserve the culture and the organization, and maximize the benefits emanating from the culture. 
We can surmise that corporate culture affects the firm's employment, board, and financial structures. We hypothesize that strong-culture firms are more likely to retain incumbent employees, promote managers from within, and reduce the probability of default and hostile takeovers than weak-culture firms. We will explain these hypotheses in the next section.

\section{Hypotheses}

We explore the effect of culture on corporate policies by analyzing whether strong-culture firms tend to select employment, board, and financial structures that help to preserve their own culture and organization. Previous research has defined a culture to be strong if norms and values are widely shared and intensely held throughout an organization (O'Reilly and Chatman, 1996). We have developed the following hypotheses to help explain the relationship between the strength of corporate culture and corporate policies and structures.

Hypothesis 1 (long-term employment):

Strong-culture firms are more likely to adopt long-term employment policies than weak-culture firms.

As long as their corporate culture is embedded into their employees, strong-culture firms are more likely to retain their incumbent employees than weak-culture firms. Employees with high levels of cultural knowledge are an important foundation of organizational capital. Strong-culture firms tend to hold on to incumbent employees rather than hire new workers from labor markets. At the same time, their long-term employment policies encourage younger employees to make culture-specific 
investments to increase future organizational capital. ${ }^{3}$ Thus, we can assume that strong-culture firms are more likely to take long-term employment policies than weak-culture firms.

Hypothesis 2 (internally promoted managers)

Managers promoted from within firms comprise a greater percentage of the management teams at strong-culture firms than at weak-culture firms.

It is assumed that managers need to fully understand a firm's culture in order to run the firm efficiently. Since a culture consists of values, beliefs, and subtle interpretations, internally promoted managers who have worked for the company for a long time have an advantage over managers appointed from the outside with respect to knowledge of the firm's culture. Chowdhry and Garmaise (2004) formulated a model that shows that cultural complementarity exists among members of an organization. They suggest that the culture embedded into employees is functional only when it is also embraced by the management. Therefore, the optimal choice for strong-culture firms would be to recruit more managers from within their firms to their management teams. ${ }^{4}$

\section{Hypothesis 3 (low leverage)}

Strong-culture firms have less debt than weak-culture firms.

Zingales (2000) argues that financial distress inflicts higher costs on firms with large amounts of organizational capital because the distress not only has financial

\footnotetext{
3 In their model, Carrillo and Gromb (2007) argue that even when a firm conducts restructuring, it is preferable to restructure in a way that is compatible with the existing culture, because culturally compatible restructuring will not discourage employees' culture-specific investments.

${ }^{4}$ Collins and Porras (1994) claim that in long-standing companies with strong cultures (which they categorize as "visionary" companies), management teams consist of internally promoted managers. Ouchi (1981) also point outs that Hewlett-Packard, which is known as a strong-culture firm, had avoided hiring managers from outside the firm.
} 
repercussions but also destroys the organizational capital. His argument suggests that because strong-culture firms have a greater amount of organizational capital than weak-culture firms, they are more eager to avoid financial distress. Since the possibility of financial distress depends not only on a firm's performance but also on its leverage, strong-culture firms should make capital structure decisions that lead to lower debt ratios. In fact, Donaldson (1984) suggests that corporate managers like to be able to rely on internally generated cash flow, rather than debt, to stay in business. We conjecture that his observation is more likely to apply to strong-culture firms.

\section{Hypothesis 4 (interlocking shareholding)}

Interlocking shareholdings are more likely to be observed in strong-culture firms than in weak-culture firms.

Iwai (2002) argues that the value of companies characterized by firm-specific organizational capital will increase when outside shareholders exercise weaker control; and that tighter control by outside shareholders increases the probability of hostile takeovers, causing the hold-up problem that prevents employees from investing in firm-specific human assets. Zingales (2000) also raises questions about whether control should reside in the hands of shareholders, given the importance of organizational capital. He accepts the possibility that "the pursuit of shareholders' value maximization may lead to inefficient actions, such as the breach of valuable implicit contracts,” as described by Shleifer and Summers (1988, p. 1635). If we consider corporate culture to be a form of organizational capital, we can predict that strong-culture firms have more incentives to weaken the control of outside shareholders in order to protect their employees' rights. In Japan, interlocking shareholdings are widely perceived to be a means of reducing the probability of hostile 
takeovers and blocking intervention by outside shareholders (Sheard 1994). Hence, we can hypothesize that strong-culture firms are more likely to form interlocking relationships with banks and other affiliated companies.

\section{Empirical Analysis}

\subsection{Measures of Cultural Strength}

We explore the relationship between corporate culture and corporate policies by testing the hypotheses presented in the previous section, using a sample of large Japanese firms. The corporate cultures of Japanese firms have attracted much attention from the 1980s, since they were thought to be a source of their competitive edge in global markets (Ouchi, 1981: Pascale and Athos, 1981). Despite this attention, however, little quantitative evidence on the importance of corporate culture for Japanese firms has been presented. Our study seeks to fill this gap.

In previous studies on corporate culture, measuring a firm’s cultural strength has always been an issue. Denison (1984) measures cultural strength by assessing the consistency of responses to his survey items across managers in a firm. Kotter and Heskett (1992) construct cultural strength indices from their questionnaire survey of managers of rival firms in the same industry. While we recognize the advantages of these survey approaches, we adopt a different method which utilizes information on corporate mission statements.

A mission statement is a company's written statement of its core values, mission, purpose, goals, principles, and norms. While it is believed that a large number of firms have mission statements, it is not always clear whether the mission statement has been fully implemented by a particular firm. However, the advantage of using the mission statement as a proxy for corporate culture is that it puts into writing those 
norms and values that a corporation requires employees to share and adopt, and hence can be considered to be an explicit declaration of the corporate culture.

Hence, we measure the cultural strength of each firm by examining whether a firm has a formal mission statement. We assume that firms with formal mission statements have stronger cultures than those without such statements. This assumption appears to be valid for Japanese firms. After conducting interview research on Japanese firms, Ouchi (1981) suggested that defining a mission statement is the first step in creating a cooperative corporate culture. Itami and Kagono (1989) claim, in their Japanese textbook on management and business, that formulating a formal mission statement is the primary method to ensure that an organizational culture will be widely shared and transmitted over generations.

In addition, we also measure the cultural strength of each firm by examining whether a firm has taken concrete and effective steps to embed the mission statement into employees. We believe that the strength of corporate culture depends not only on whether a firm has a mission statement, but also on how effectively the mission statement is embedded among employees. It is natural to assume that among firms with formal mission statements, those with some concrete and effective means of transmitting their content to employees have stronger cultures than firms without such means.

\subsection{Sample}

We obtained mission statement data on Japanese firms from Kigyo Kodo Shishin Jitsureishu (hereafter, KKSJ), which is based on a survey of companies' mission statements conducted by Nikkeiren in June 1997. KKSJ, which was published in 1997, contains the mission statements of 207 responding Japanese firms and the concrete 
measures (if any) that firms took to embed the content of these statements into their organization.

From these 207 firms we selected our sample according to the following criteria. First, the firm had to be listed on the First Section of the Tokyo Stock Exchange and could be in any industry except finance, electricity, and gas. ${ }^{5}$ This criterion limited our sample to non-financial, non-regulated, and large-sized firms. Second, a firm's formal mission statement had to be disclosed on its internet homepage in July 2003. This criterion ensures that a firm has maintained its formal mission statement over time and therefore could be considered to have a strong culture. Applying these criteria left us with 64 firms.

Since we test the impact of the mission statement on corporate policies and performance using the firms' data from the mid-1980s, sample firms should have introduced mission statements, either the current version or an previous version, prior to the mid-1980s, We checked when the identified mission statements of sample firms were introduced through company handbooks and other sources. Twenty-two of the 64 firms established the current version of their mission statement before 1986, and continued to use it. Although the remaining 42 firms introduced the current version of their mission statement after 1986, they are based on older versions of mission statements which have been repeatedly revised. ${ }^{6}$ Thus, the final sample consists of 64 firms with enduring mission statements and for that reason they are considered strong-culture firms.

\footnotetext{
5 We exclude firms in these three regulated industries because they are subject to regulations which may encourage them to adopt different policies determining employment, board, and financial structures than the policies adopted by firms in unregulated industries.

${ }^{6}$ For 39 firms of these 42 firms, we were able to identify when the former version of the mission statement was introduced, while the mission statements of the remaining three are too old to identify a date of introduction.
} 
For each of the 64 strong-culture firms, we found a matching firm that is in the same industry as a strong-culture firm, ${ }^{7}$ and also listed on the First Section of the Tokyo Stock Exchange, but was found not to have a formal mission statement. We selected the matching sample firms according to the following criteria, i) the firm is not included in KKSJ, ii) the firm's formal mission statement did not appear on its internet homepage in July 2003; and iii) among those firms satisfying the above two criteria, the firm's total assets were closest in value to the assets of the strong-culture firm. Following these criteria, we obtained 64 matching sample firms, which we categorize as weak-culture firms. In Table 1, we list the 64 strong-culture firms and their matching weak-culture firms with their Tokyo Stock Exchange (TSE) codes.

For the sample of 64 strong-culture firms, we obtained information from KKSJ on whether each had taken any practical and concrete steps to embed the content of the mission statement into employees. We found that $75 \%$ of strong-culture firms have taken some embedding steps: $31.25 \%$ of the firms put up posters or a framed copy of the mission statement in places of high visibility; $25 \%$ of the firms teach the mission statement to current employees in training programs; $21.87 \%$ of the firms deliver a mission statement booklet to employees; the top management (president or CEO) of $18.75 \%$ of the firms is engaged in embedding the mission statement through speeches, written statements, and direct teaching in the training programs and in day to day operations, etc.; $17.18 \%$ of the firms published the mission statement in in-house magazines; other steps include training programs for newly hired employees, affirmations and pledges recited at every morning assembly, distribution of mission statement cards, establishment of internal schools and training centers to teach the

\footnotetext{
${ }^{7}$ We used the Tokyo Stock Exchange industry classification scheme which categorizes Japanese firms into 33 industries.
} 
mission statement, etc.

Based on the information from 64 strong-culture firms, we then chose firms whose cultures seemed to be embedded more deeply and intensively. To do this, we used two criteria. We first checked whether the top management (president or CEO) is engaged in transmitting the mission statement. Schein (1985) suggests that the leader's attention to culture and deliberate role in teaching it are crucial, and personal involvement by a corporate leader is a powerful primary mechanism for culture embedding and reinforcement. As we saw above, the engagement of the upper echelon of management is observed for $18.75 \%$ of the strong-culture firms. We then checked whether a firm has any training system for instilling the mission statement. Itami and Kagono (1989) and Collins and Porras (1994) stress the importance of training for transmitting culture. Kitai and Matsuda's (2002) empirical study on Japanese firms shows that training for newly hired employees as well as teaching by top management are significantly effective in embedding culture. We selected firms which had at least one of the following training systems to instill the mission statement: training programs for current employees or newly hired employees; affirmations and pledges at every morning assembly; internal schools or training centers dedicated to instilling the mission statement. Of the strong-culture firms, $45.31 \%$ had taken such steps.

\subsection{Regression Equations}

To test hypothesis 1 , the relation between cultural strength and employment policy, we estimate the following equations.

$$
\begin{aligned}
& E M P=\alpha_{1}+\beta_{1} C U L T U R E+\gamma_{1} \ln T A+\delta_{1} A G E+\varepsilon_{1} \\
& E M P=\alpha_{2}+\left(\beta_{20}+\beta_{21} T O P+\beta_{22} \text { TRAIN }\right) C U L T U R E+\gamma_{2} \ln T A+\delta_{2} A G E+\varepsilon_{2}
\end{aligned}
$$


In (1-1), EMP is the average length of service of the employees (years), CULTURE is a dummy variable that takes 1 if a firm is a strong-culture firm (a firm with a formal mission statement), $\ln T A$ is the logarithm of book value of total assets (million yen), $A G E$ is a firm's age (years), and $\varepsilon_{1}$ is the error term. If strong-culture firms tend to have a policy of longer-term employment, the coefficient of CULTURE $\left(\beta_{1}\right)$ should be positive. In (1-2), we add two dummy variables on the degree of culture embedding, mentioned in the previous subsection, to the coefficient of CULTURE; TOP takes 1 if the top management (president or CEO) is engaged in transmitting the mission statement, and TRAIN takes 1 if at least one of the training systems (training programs, affirmations and pledges at morning assembly, internal schools or training centers) are used to instill the mission statement. From Hypothesis 1, even among strong-culture firms in our sample, firms with more deeply embedded cultures are more likely to retain incumbent employees. Therefore the coefficients of TOP $\times \operatorname{CULTURE}\left(\beta_{21}\right)$ and TRAIN $\times$ CULTURE, $\left(\beta_{22}\right)$ should be positive.

To test Hypothesis 2, the relation between corporate culture and internally promoted managers, we estimate the regression equations of INSIDER, the insider board ratio (\%), [1 - the number of outside directors / the number of members of the board of directors $] \times 100$, using the same independent variables as those in (1-1) and (1-2). In most Japanese companies, and particularly until the 2000s, the management team and the board of directors had not been separated, and the board members overlapped with top management. Therefore, the ratio of internally promoted managers among the management team can be measured by the ratio of insider directors among the board. If Hypothesis 2 is valid, the effect of CULTURE on INSIDER should be positive and the effects of TOP $\times$ CULTURE and TRAIN $\times$ CULTURE should be positive. 
To test Hypotheses 3 and 4, the effects of culture on capital structure and interlocking shareholdings, we estimate the regression equations of DEBT (the debt to asset ratio (\%) calculated as [total liabilities / the book value of the total assets] $\times 100$ ) and INTERLOCK (the interlocking share ratio (\%) calculated as [the number of interlocking shares / total number of shares outstanding] $\times 100$ ), respectively, using the same independent variables as those in (1-1) and (1-2). If the cultural strength is negatively related to the debt to asset ratio and positively related to the degree of interlocking shareholdings, the coefficients of CULTURE, TOP $\times$ CULTURE, and TRAIN $\times$ CULTURE should be negative in the DEBT equations, and positive in the INTERLOCK equations.

Furthermore, to check the robustness of our results, we also estimate the regression equation by adding two more control variables to each of the equations. These two variables are $R O A$ (operating income to the book value of total assets; \%) and $M K T B K$ (market-to-book ratio; market value of the total assets to book value of the total assets). Including these two variables is important because a firm's profitability $(R O A)$ and its growth opportunities (MKTBK) may affect corporate policies and structures. In particular, previous studies have shown that with regard to capital structure decisions, these two factors have significant effects on debt to asset ratios (e.g. Harris and Raviv 1991, Rajan and Zingales 1995). Therefore adding ROA and $M K T B K$ to the equations is necessary to avoid omitted variable bias. In addition, by including these control variables, we can compare the economic significance of the cultural effects on dependent variables with the other factors' effects.

All financial data except INTERLOCK are obtained from the Nikkei NEEDS financial database. INTERLOCK is obtained from Mochiai Jokyo Chosa (Cross-Shareholding Survey) by Nippon Life Insurance Research Institute. We 
estimated the regressions by OLS, using 15 years of panel data from 1986 to 2000 for sample firms ${ }^{8}$. As for the cultural variables (CULTURE, TOP, and TRAIN), we used the same value ( 0 or 1 ) for the same firm throughout the sample period. We also added the year dummies to all regressions to control for year-specific effects.

\section{Empirical Results}

\subsection{Content of Mission Statements}

Table 2 provides details on the content of mission statements of 64 strong-culture firms including corporate values, objectives, norms, and behavioral standards. The content of these mission statements suggests that they are written declarations of the firms' corporate cultures. Panel A shows corporate values, objectives, and philosophies. As can be seen, the majority (71.9\%) of firm have mission statements that refer to the need to "contribute to society, happiness of mankind, the creation of culture, and global prosperity." Another striking feature is that only $6.3 \%$ of firms voice "concern for the interests of shareholders,” while many of them emphasize concern for employees. For example, $37.5 \%$ of the firms state that it is their mission to provide worthwhile and fulfilling work for their employees. Panel B shows the types of norms and behavioral standards contained in mission statements. Almost half, or $45.3 \%$ of the firms, refer to "innovation and originality" in their mission statements. "Conscientiousness and cordiality on the job" and "rise to the challenge and aggressiveness" appear in the mission statements of $31.3 \%$ and $18.8 \%$ of the firms, respectively.

\footnotetext{
${ }^{8}$ When we were unable to obtain a particular year's data for either a strong-culture firm or its matching weak-culture firm, we did not use that year's data for both firms.
} 


\subsection{Descriptive Statistics}

The means and standard deviations of the dependent and independent variables in the regression equations are summarized in Table $3 .^{9}$ The first column (Total Sample) shows the statistics for 128 firms over our sample period (1986-2000). The second and third columns (Strong Culture Firms, Weak Culture Firms) provide the statistics for 64 strong-culture firms and 64 weak-culture firms, respectively. The fourth column (Difference) is the difference in the means of each variable for the strong-culture firms and the weak-culture firms. We notice that the mean length of service of employees $(E M P)$ for strong-culture firms (16.35) is larger than that for weak-culture firms (15.56) and the difference (0.79) is statistically significant at less than the $1 \%$ level $(\mathrm{p}$-value $=0.000)$. This is consistent with Hypothesis 1: strong-culture firms are more likely to adopt long-term employment policies than weak-culture firms. We also observe that the mean of the insider board ratio (INSIDER) is significantly higher for the strong-culture firms (92.60) than for the weak-culture firms (87.89); this supports Hypothesis 2. As for the capital structure, the debt ratio (DEBT) of the strong-culture firms (63.26) is a little higher than that of the weak-culture firms (62.43), but the difference is not statistically significant. In addition, the interlocking share ratio (INTERLOCK) is significantly higher for the strong-culture firms (28.91) than for the weak-culture firms (23.59); this is also consistent with Hypothesis 4. As for the control variables, $\ln T A$, AGE and $R O A$ are significantly higher for the strong-culture firms than for the weak-culture firms. This supports our decision to control for size, age, and profitability in the regressions.

\footnotetext{
9 Table 3 also includes the statistics for PARENT (parent firm's shareholdings ratio) and FOREIGN (foreign investors' shareholdings ratio), which will be used in the analysis in section 5.4.
} 


\subsection{Regression Results}

The regression results are summarized in Tables 4, 5, 6, and 7. First, Table 4 shows the results of the employment policy regressions. Looking at column (1-1), we find that CULTURE has a significantly positive coefficient $(0.593, \mathrm{p}=0.001)$. This result holds for column (1-1)', which is regressed on $R O A$ and $M K T B K$. These results indicate that the length of service of the employees is longer for the strong-culture firms than for the weak-culture firms. This supports Hypothesis 1 (strong-culture firms are more likely to adopt long-term employment policies than weak-culture firms), and suggests that corporate culture does affect a firm's employment policy.

In Table 4, it is also interesting to examine the results of (1-2) and (1-2)' where two variables for the degree of culture embedding are introduced in the regression. We find that in (1-2)' the coefficients of TOP $x$ CULTURE and TRAIN $x$ CULTURE are significantly positive at the $1 \%$ and $10 \%$ level, respectively. This suggests that even among strong-culture firms, a firm is more likely to retain current employees once its culture is more deeply embedded into its organization. Firms appear to consider employees who embody the firm's culture as accumulated organizational capital.

We should also note that the effect of culture on the firm's employment policy is not only statistically significant but also of considerable magnitude. The result (1-2)' indicates that if a firm has a strong culture and top management is engaged in culture transmission, its EMP is $1.227(=0.247+0.980)$ years longer than that of weak-culture firms. Moreover, if this firm has some cultural training systems as well, its EMP is $1.684(=0.247+0.980+0.457)$ years longer than that of weak-culture firms. These culture effects are much larger than effects of other factors on employment policy. We can measure the effects of other factors by the effect of a one-standard-deviation 
change in other independent variables on $E M P$, which is computed as the estimated coefficient of each variable $\times$ one standard deviation of each variable. We computed this for each variable and found that $A G E$ had the largest effect among the other variables: the $A G E$ effect equals $0.690(=0.040 \times 17.25)$ years. This $A G E$ effect is, however, only about 40-55 percent as large as the above culture effect. This implies that corporate culture and its strength are crucial determinants of corporate employment policy.

Table 5 provides regression results on the insider board ratio. The results (2-1) and $(2-1)^{\prime}$ indicate that the coefficient of CULTURE is positive and statistically significant at the 1\% confidence level. These results support Hypothesis 2: firms with stronger cultures tend to have more internally promoted managers. ${ }^{10}$ On the other hand, the results (2-2) and (2-2)' show that the effects of two culture embedding variables (TOP $\times$ CULTURE and TRAIN $\times$ CULTURE) do not have significant effects. However, from (2-2)', we confirm that the magnitude of the culture effect is considerable for the board structure as well. The estimated coefficient of CULTURE, 4.179, indicates that the insider board ratio is 4.179 percentage points higher for strong-culture firms than for weak-culture firms. This effect is the largest among the effects of all factors, with respect to board structure. The effect of a one standard deviation change in AGE on INSIDER is only $2.243(=0.130 \times 17.25)$ percentage points, and the effect of $R O A$ and $\operatorname{lnTA}$ is $1.374(=0.469 \times 2.93)$ percentage points and $0.880(=0.672 \times 1.31)$ percentage points, respectively. These results allow us to conclude that corporate culture significantly affects the firm's board structure.

\footnotetext{
${ }_{10}$ This result appears to contrast with the findings of Cronqvist, Low, and Nilsson (2007). They find that commonality in spinoff and parent firms' policies is still observed even when the spinoff CEOs are outsiders, suggesting that the appointment of outside managers does not necessarily trigger clashes of corporate cultures.
} 
Table 6 summarizes the regression results on the debt-to-asset ratio (DEBT). The results (3-1) and (3-1)' indicate that CULTURE has a statistically significant negative effect on the firm's leverage. This supports Hypothesis 3: strong-culture firms tend to have less debt. In addition, the results of (3-2) and (3-2) show that the coefficients of TOP $\times$ CULTURE as well as those of CULTURE are significantly negative. These results suggest that corporate culture and its strength affect even the firm's capital structure decisions. While there have been extensive studies on capital structure, we provide the first evidence that the strength of corporate culture is a determinant of the firm's capital structure choice. Our result seems intuitive once we regard corporate culture as organizational capital which depreciates in the face of financial distress.

In fact, the magnitude of the culture effect is significant in the debt to asset ratio regressions. The result (3-2)' indicates that if a firm has a strong culture with top management engagement in embedding, the debt to asset ratio decreases by 5.099 $(2.504+2.595)$ percentage points. The magnitude of the culture effect is similar to that of the effects of other factors such as size, profitability, and growth opportunities which are well known as determinants of capital structure from previous studies (e.g. Harris and Raviv 1991, Rajan and Zingales 1995). The effect of a one standard deviation change in $\operatorname{lnTA}$ is $5.921(=4.520 \times 1.31)$ percentage points; the effect of $R O A$ is -4.225 $(=-1.442 \times 2.93)$ percentage points; the effect of MKTBK is $-2.017(=-3.202 \times 0.63)$ percentage points, respectively. Our results suggest that corporate culture matters in determining capital structure and that the firm-specific capital or organizational capital significantly affects corporate finance policies.

Table 7 summarizes the regression results on interlocking shareholdings. The results (4-1) and (4-1)' indicate that CULTURE has significantly positive effects on 
interlocking shareholdings. For example, the result (4-1)' shows that the interlocking share ratio of strong-culture firms is 5.671 percentage points higher than that of the weak-culture firms, ceteris paribus. This result supports Hypothesis 4: interlocking shareholdings are more likely to be observed in strong-culture firms. On the other hand, the results in (4-2) and (4-2)' show complex relationships between cultural strength and the interlocking shareholdings. While the coefficients of CULTURE are significantly positive in (4-2) and (4-2)', the coefficients of the culture embedding variables, TOP $\times$ CULTURE and TRAIN $\times$ CULTURE, are significantly negative. This suggests that the relationship between cultural strength and the interlocking shareholdings is non-linear; if corporate culture is formalized by the mission statement, the degree of the interlocking shareholdings increases; but as the culture is transmitted to and embedded into the organization, the degree of interlocking shareholdings decreases.

The negative relationship between culture embedding and interlocking shareholdings is inconsistent with Hypothesis 4. Why do we observe such a negative relationship? One possible explanation is that hostile takeovers are less likely to occur as corporate culture is more deeply embedded into the organization. Once cultural strength reaches a significant level, allowing the firm to enjoy a competitive advantage from its strong culture, outside investors will not take over the firm because they know that doing so would destroy the corporate culture and decrease the firm's value. If the decline in shareholder value arising from the decrease in the firm's value is greater than the rent extracted from the takeovers, outside investors are deprived of their incentive to implement a hostile takeover. In that case, the employees do not have to worry about the hold-up problem and the necessity of interlocking shareholdings decreases. This may be the reason we obtained negative signs for the culture 
embedding variables in (4-2) and (4-2)'. ${ }^{11}$

\subsection{Corporate Culture and Performance}

We have found that corporate culture is an important determinant of a firm's employment policy, board, and capital structures, and interlocking shareholdings. Lastly, we examine whether corporate culture affects corporate performance. Since culture can be considered essential organizational capital, we predict that it raises productivity and contributes to superior performance, and put forth the following hypothesis.

\section{Hypothesis 5 (superior performance)}

Strong-culture firms perform better than weak-culture firms.

Previous studies have not presented convincing evidence to validate this hypothesis. While many studies have maintained that corporate culture improves corporate performance, there is also research that suggests that culture, especially nonadaptive versions, may undermine performance (Kotter and Heskett 1992). In addition, as mentioned earlier, the quantitative evidence to prove that culture has a positive effect on performance is scant aside from the findings presented in a small number of exceptional works such as Denison (1984), Gordon and DiTomaso (1992), Kotter and

11 This explanation is consistent with interview evidence on the relationship between organizational capital and the possibility of hostile takeover. We interviewed an executive of a Japanese general trading company whose competitive edge comes from human assets. He said that hostile takeovers are unlikely to target general trading companies because even if a takeover were to occur, it would decrease shareholders' value because core employees would depart and organizational capital would depreciate. Rajan and Zingales (2000) report that in the U.K. this actually happened to a British advertising agency, Saatchi and Saatchi. In addition, we also interviewed an executive of a Japanese precision machinery company whose excellent performance appeared to come from its R\&D capabilities. He said that "raiders may be able to take over our company, but would not be able to manage it." He seemed to imply that any outside investors who recognized their inability to manage his company would not attempt a takeover. These interview results suggest companies whose competitiveness stems mainly from organizational capital are less likely to become targets of hostile takeovers. 
Heskett (1992), and Sorensen (2002). To provide further evidence that culture and its strength affects performance, we use data from Japanese firms to run the performance regressions.

As a dependent variable, we adopt $R O A$ (operating income to the book value of total assets; \%). Independent variables include the culture variables (CULTURE, TOP $\times$ CULTURE, and TRAIN $\times$ CULTURE) and the size and age variables (InTA, and AGE) defined in subsection 4-3. From Hypothesis 5, we predict the coefficient of CULTURE and the coefficients of TOP $\times$ CULTURE and TRAIN $\times$ CULTURE will be positive. We also estimate each regression equation including two control variables. These two variables are PARENT, parent company's shareholdings ratio (\%; the ratio of the shares held by the top shareholder whose holdings ratio exceeds $15 \%$ ), and FOREIGN, the foreign investors' shareholdings ratio (\%; the ratio of the shares held by foreign investors). These variables are included to control for the effects of the external managerial discipline on corporate performance. The data for PARENT and FOREIGN are obtained from Mochiai Jokyo Chosa (Cross-Shareholding Survey) by Nippon Life Insurance Research Institute and Okabunushi Soran (Directory of Large Shareholders) by Toyo Keizai Shinposha, respectively. Their means and standard deviations are shown in Table 3.

As explained earlier, we estimated the regressions by OLS, using 15 years of panel data from 1986 to 2000 for 128 firms. Table 8 summarizes the regression results. The results (5-1) and (5-1)' show that CULTURE has significant positive coefficients. These results support Hypothesis 5: strong-culture firms perform better than weak-culture firms. Therefore, our findings indicate that corporate culture does enhance the corporate performance of Japanese firms.

In addition, the results (5-2) and (5-2)' show that culture embedding is crucial 
for better performance; while the coefficients of TOP $\times$ CULTURE are insignificant, those of TRAIN $\times$ CULTURE are significantly positive at the $1 \%$ level. The result (5-2)' indicates that if a firm has a strong culture with some cultural training systems in place, its $R O A$ is $0.836(=0.013+0.823)$ percentage points higher than that of weak-culture firms. This culture effect is much larger than the size and age effects on $R O A$. The effect of a one standard deviation change in $\ln T A$ and AGE on ROA is only $-0.267(=-0.204 \times 1.31)$ percentage points and $-0.155(=-0.009 \times 17.25)$ percentage points, respectively. At the same time, we also found that the magnitude of the culture effect (0.836) is greater than the external discipline effect on $R O A$. Making a further comparison with corporate governance variables, we find that the effect of a one standard deviation change in PARENT and FOREIGN on ROA is $0.442(=0.029 \times$ 15.27) percentage points and $0.832(=0.110 \times 7.57)$ percentage points, respectively. These results allow us to assert that corporate culture and its cultural strength are important determinants of corporate performance in Japan, with performance effects that are larger than or at least the same magnitude as those of corporate governance variables.

\section{Concluding Remarks}

In conclusion, we state once again that corporate culture does matter. Using data on Japanese firms from 1986 to 2000, when Japanese firms faced large business fluctuations stemming from the burgeoning and bursting of the bubble, and subsequent prolonged recession, we have shown that corporate culture and cultural strength significantly influence corporate policies affecting employment, board, and financial structures. At the same time, we have also confirmed that culture and the embedding of culture enhance corporate performance. These culture effects are found to be 
considerable in magnitude and greater than other factors. Corporate culture, often viewed as unobservable, ambiguous, and hard to measure by academics, is a crucial determinant of corporate policies and performance.

Japanese companies have long been thought to have derived competitive advantages from the corporate cultures that they have developed (Ouchi, 1981: Pascale and Athos,1981). Scholars, however, have provided little quantitative evidence that would prove the importance of culture to Japanese firms. Through business upturns and downturns, strong-culture firms are more likely to adopt policies that encourage long-term employment, and to have more managers promoted from within than weak-culture firms. Strong-culture firms are also more likely to have lower debt levels, and a higher percentage of interlocking shareholdings than weak-culture firms. We provide evidence here that indicates that strong-culture Japanese firms consider culture to be a form of organizational capital which has significant effects on their strategies and policies.

The finance literature suggests that some of the above policy choices would result in lower performance and potential agency problems. For example, lower debt levels are often associated with the free cash flow problem and interlocking shareholdings are thought to induce insider control problems (Jensen,1986: Miyajima and Kuroki, 2007). Surprisingly enough, firms with strong culture achieved relatively higher levels of performance throughout this period. This result indicates that corporate culture enhances corporate performance in the long run.

Our empirical results also help us to understand the organizational behavior of Japanese firms in recent years. During the long economic downturn from the 1990s to 2000s in Japan (sometimes called "the lost decade”), Japanese firms were criticized in the press and mass media for their resistance to change. The firms did not lay off 
employees in spite of their lower profitability, and were accused of placing too much importance on financial stability and not enough on dividends to shareholders. In addition, most firms did not seem to have made the transition to U.S.-style, shareholder-oriented corporate governance systems, and only a small percentage of Japanese firms appointed outsiders to their boards of directors. However, our empirical results suggest that the seemingly conservative behavior of Japanese firms can in fact be viewed as a reflection of decisions that were rationally made in order to maintain their corporate culture as a source of competitive advantage. Our findings suggest that recognizing the importance of culture will enable us to view corporations and corporate policies in a new light.

\section{Acknowledgements}

This paper was presented at RIETI (Research Institute of Economy, Trade, and Industry), Nomura Securities, and the Japan Economic Association Annual Meeting. We wish to thank Hideshi Itoh and other workshop participants for valuable comments and suggestions on earlier drafts of the paper. This research was supported in part with a grant from Seimeikai and the Open Research Center Project for Private Universities. 


\section{References}

Besanko, D., D. Dranove, M. Shanley, and S. Schaefer (2007), Economics of Strategy (4th ed.), John Wiley \& Sons: Hoboken, NJ.

Carrillo, J. D. and D. Gromb (2007), "Cultural Inertia and Uniformity in Organizations,” Journal of Law, Economics, and Organization 23, pp. 743-771.

Chowdhry, B. and M. J. Garmaise (2004), “Organization Capital and Intrafirm Communication,” mimeo.

Collins, C. C. and J. I. Porras (1994), Built to Last: Successful Habits of Visionary Companies, Harper Business: New York.

Cremer, J. (1993), “Corporate Culture and Shared Knowledge,” Industrial and Corporate Change 101, pp.351-386.

Cronqvist, H., A. Low, and M. Nilsson (2007), "Does Corporate Culture Matter for Investment and Financial Policies?” Ohio State University Fisher School of Business Working Paper No. 2007-03-001.

Deal, T. and A. Kennedy (1982), Corporate Cultures, Addison-Wesley: Reading, MA.

Denison, D. R. (1984), "Bringing Corporate Culture to the Bottom Line," Organizational Dynamics 13, pp. 5-22.

Donaldson, G. (1984), Managing Corporate Wealth: The Operations of a Comprehensive Financial Goals System, Praeger Publishers: Westport, CT.

Gordon, G. G. and N. DiTomaso (1992), "Predicting Corporate Performance from Organizational Culture,” Journal of Management Studies 29, pp. 783-798.

Harris, M. and A. Raviv (1991), “The Theory of Capital Structure,” Journal of Finance 46, pp.297-355.

Hermalin, B. E. (2001), "Economics and Corporate Culture,” in C. L. Cooper, S. Cartwright, and P. C. Earley (eds.), The International Handbook of Organizational Culture and Climate, John Wiley \& Sons: New York:

Hodgeson, G. M. (1996), “Corporate Culture and the Nature of the Firm,” in J. Groenewegen (ed.), Transaction Cost Economies and Beyond, Kluwer Academic Press: Boston. 
Itami, H. and T. Kagono (1989), Zeminaru Keieigaku Nyumon (Seminar: Introduction to Management), Nihon Keizai Shinbunsha: Tokyo. (in Japanese)

Iwai, K. (2002), “The Nature of the Business Corporation: Its Legal Structure and Economic Functions,” Japanese Economic Review 53, pp. 243-273.

Jensen, M. (1986), “Agency Costs of Free-Cash Flow, Corporate Finance, and Takeovers,” American Economic Review 76, pp. 323-339.

Kitai, A. and Y. Matsuda (2002), "Nihon Kigyo ni okeru Rinen Shinto Katsudo to Sono Kouka,” in T. Kagono, A. Sakashita, and T. Inoue (eds.), Nihon Kigyo no Senryaku Infura no Henbo (Strategic Infrastructure), Hakuto Shobo: Tokyo. (in Japanese)

Kotter, J. P. and J. L. Heskett (1992), Corporate Culture and Performance, Free Press: New York.

Lev, B. and S. Radhakrishnan (2004), “The Valuation of Organization Capital," mimeo.

Miyajima, H. and F. Kuroki (2007), “The Unwinding of Cross-Shareholding in Japan: Causes, Effects, and Implications,” in M. Aoki, G. Jackson, and H. Miyajima (eds.), Corporate Governance in Japan, Oxford University Press: Oxford.

O’Reilly, C. A. and J. A. Chatman (1996), “Culture as Social Control: Corporations, Culture and Commitment,” in B. M. Staw and L. L. Cummings (eds.), Research in Organizational Behavior Vol. 18, JAI Press: Greenwich, CT.

Ouchi, W. (1981), Theory Z: How American Business Can Meet the Japanese Challenge, Addison-Wesley: Reading, MA.

Pascale, R. T. and A. G. Athos (1981), The Art of Japanese Management, Simon and Schuster: New York.

Prescott, E. C. and M. Visscher (1980), “Organizational Capital,” Journal of Political Economy 88, pp. 446-461.

Rajan, R. and L. Zingales (1995), "What Do We Know about Capital Structure? Some Evidence from International Data,” Journal of Finance 50, pp.1421-1458.

Rajan, R. and L. Zingales (2000), "The Governance of New Enterprise,” in X. Vives, (ed.), Corporate Governance, Cambridge University Press: Cambridge.

Schein, E. H. (1985), Organizational Culture and Leadership, Jossey-Bass Publishers: 
San Francisco.

Sheard, P. (1994), “Interlocking Shareholdings and Corporate Governance," in M. Aoki and R. Dore (eds.), The Japanese Firm: Sources of Competitive Strength, Oxford University Press: Oxford..

Shleifer, A. and L. Summers (1988), "Breach of Trust in Hostile Takeovers," in A. J. Auerbach (ed.), Corporate Takeovers: Causes and Consequences, University of Chicago Press: Chicago.

Sorensen, J. B. (2002), “The Strength of Corporate Culture and the Reliability of Firm Performance,” Administrative Science Quarterly 47, pp. 70-91.

White, H. (1980), "Heteroskedasticity-Consistent Covariance Matrix Estimator and a Direct Test for Heteroskedasticity,” Econometrica, 48, pp. 817-838.

Zingales, L. (2000), “In Search of New Foundations,” Journal of Finance 55, pp. 1623-1653. 
Table 1 Sample Firms

\begin{tabular}{|c|c|c|c|}
\hline \multicolumn{2}{|c|}{ Strong Culture Firms (64 firms) } & \multicolumn{2}{|c|}{ Weak Culture Firms (64 firms) } \\
\hline TSE Code & Company's Name & TSE Code & Company's Name \\
\hline 1332 & Nippon Suisan Kaisha, Ltd. & 1377 & Sakata Seed Corp. \\
\hline 1801 & Taisei Corp. & 1886 & Aoki Corp. \\
\hline 1802 & Obayashi Corp. & 1812 & Kajima Corp. \\
\hline 1804 & Sato Kogyo Co., Ltd. & 1833 & Okumura Corp. \\
\hline 1824 & Maeda Corp. & 1821 & Mitsui Construction Co., Ltd. \\
\hline 1911 & Sumitomo Forestry Co., Ltd. & 1868 & Mitsui Home Co., Ltd. \\
\hline 1941 & Chudenko Corp. & 1946 & Toenec Corp. \\
\hline 2202 & Meiji Seika Kaisha, Ltd. & 2211 & Fujiya Co., Ltd. \\
\hline 2502 & Asahi Breweries, Ltd. & 2501 & Sapporo Breweries, Ltd. \\
\hline 3105 & Nisshinbo Industries, Inc. & 3106 & Kurabo Industries Ltd. \\
\hline 3407 & Asahi Chemical Industry Co., Ltd. & 4005 & Sumitomo Chemical Co., Ltd. \\
\hline 3591 & Wacoal Co., Ltd. & 3501 & Suminoe Textile Co., Ltd. \\
\hline 4023 & Kureha Chemical Co., Ltd. & 4186 & Tokyo Ohka Kogyo Co., Ltd. \\
\hline 4204 & Sekisui Chemical Co., Ltd. & 4063 & Shin-Etsu Chemical Co., Ltd. \\
\hline 4205 & Nippon Zeon Co., Ltd. & 4028 & Ishihara Sangyo Kaisha, Ltd. \\
\hline 4403 & NOF Corp. & 4409 & Harima Chemical, Inc. \\
\hline 4452 & Kao Corp. & 4461 & Dai-ichi Kogyo Seiyaku Co., Ltd. \\
\hline 4613 & Kansai Paint Co., Ltd. & 4612 & Nippon Paint Co., Ltd. \\
\hline 5014 & Japan Energy Corp. & 5009 & Fuji Kosan Co., Ltd. \\
\hline 5101 & The Yokohama Rubber Co., Ltd. & 5110 & Sumitomo Rubber Industries, Ltd. \\
\hline 5105 & Toyo Tire \& Rubber Co., Ltd. & 5106 & The Ohtsu Tire \& Rubber Co., Ltd. \\
\hline 5201 & Asahi Glass Co., Ltd. & 5202 & Nippon Steel Glass Co., Ltd. \\
\hline 5403 & Kawasaki Steel Corp. & 5406 & Kobe Steel, Ltd \\
\hline 5471 & Daido Steel Co., Ltd. & 5476 & Nippon Koshuha Steel Co., Ltd. \\
\hline 5482 & Aichi Steel Corp. & 5632 & Mitsubishi Steel Mfg. Co., Ltd. \\
\hline 5602 & Kurimoto, Ltd. & 5633 & Kanto Special Steel Works, Ltd. \\
\hline 5991 & NHK Spring Co., Ltd. & 5716 & Nippon Mining \& Metals Co., Ltd. \\
\hline 6473 & Koyo Seiko Co., Ltd. & 6480 & Nippon Thompson Co., Ltd. \\
\hline 6501 & Hitachi, Ltd. & 6503 & Mitsubishi Electric Corp. \\
\hline 6645 & Omron Corp. & 6954 & Fanuc Ltd. \\
\hline 6701 & NEC Corp. & 6704 & Iwatsu Electric Co., Ltd. \\
\hline 6703 & Oki Electric Industry Co., Ltd. & 6815 & Uniden Corp. \\
\hline 6708 & Toyo Communication & 6759 & Tokin Corp. \\
\hline 6752 & Matsushita Electric Industrial & 6758 & Sony Corp. \\
\hline 6764 & Sanyo Electric Co., Ltd. & 6765 & Kenwood Corp. \\
\hline 6768 & Tamura Corp. & 6705 & NEC Infrontia Corp. \\
\hline 6798 & SMK Corp. & 6717 & Fujitsu Denso Ltd. \\
\hline 6845 & Yamatake Corp. & 7735 & Dainippon Screen Mfg. Co., Ltd. \\
\hline 6931 & Japan Storage Battery Co., Ltd. & 6934 & Shin-kobe Electric Machinery Co., Ltd. \\
\hline 6991 & Matsushita Electric Works, Ltd. & 6810 & Hitachi MaXell, Ltd \\
\hline 7004 & Hitachi Zosen Corp. & 6273 & SMC Corp. \\
\hline 7011 & Mitsubishi Heavy Industries, Ltd. & 6412 & Heiwa Corp. \\
\hline 7205 & Hino Motors, Ltd. & 7269 & Suzuki Motor Corp. \\
\hline 7272 & Yamaha Motor Co., Ltd. & 7222 & Nissan Shatai Co., Ltd. \\
\hline 7282 & Toyota Gosei Co., Ltd. & 7275 & Unishia Jecs Corp. \\
\hline 7701 & Shimadzu Corp. & 7744 & Noritsu Koki Co., Ltd. \\
\hline 7723 & Aichi Tokei Denki Co., Ltd. & 7724 & Kimmon Mfg. Co., Ltd. \\
\hline 7751 & Canon Inc. & 6594 & Nidec Corp. \\
\hline 7752 & Ricoh Co., Ltd. & 6146 & Disco Corp. \\
\hline 7753 & Minolta Co., Ltd. & 7732 & Topcon Corp. \\
\hline 7936 & Asics Corp. & 7955 & Cleanup Corp. \\
\hline 8001 & Itochu Corp. & 8063 & Nissho Iwai Corp. \\
\hline 8002 & Marubeni Corp. & 8031 & Mitusi \& Co., Ltd \\
\hline 8013 & Naigai Co., Ltd. & 8193 & Suzutan Co., Ltd. \\
\hline 8231 & Mitsukoshi, Ltd. & 8242 & Hankyu Department Stores, Inc. \\
\hline 8233 & Takashimaya Co., Ltd. & 8245 & Maruei Department Store Co., Ltd. \\
\hline 8238 & Isetan Co., Ltd. & 8232 & Tokyu Department Store Co., Ltd. \\
\hline 9020 & East Japan Railway Co. & 9022 & Central Japan Railway Co. \\
\hline 9031 & Nishi-Nippon Rail Road Co., Ltd. & 9009 & Keisei Electric Railway Co., Ltd. \\
\hline 9064 & Yamato Transport Co., Ltd. & 9062 & Nippon Express Co., Ltd. \\
\hline 9065 & Sankyu Inc. & 9075 & Fukuyama Transporting Co., Ltd. \\
\hline 9101 & Nippon Yusen K.K & 9104 & Mitsui O.S.K. Lines, Ltd. \\
\hline 9201 & Japan Airlines Co., Ltd. & 9231 & Kokusai Kogyo Co., Ltd. \\
\hline 9310 & Japan Transcity Corp. & 9302 & Mitsui - Soko Co., Ltd. \\
\hline
\end{tabular}


Table 2 Content of Mission Statements

\begin{tabular}{|l|c|}
\hline \multicolumn{2}{|c|}{ Panel A: Values / Philosophies/ Objectives of the Firm } \\
\hline $\begin{array}{l}\text { Contribute to society, happiness of mankind, the creation of culture, and global } \\
\text { prosperity }\end{array}$ & $71.9 \%$ \\
\hline Concern for the interests of shareholders & $6.3 \%$ \\
\hline Respect employees' livelihoods, happiness, prosperity, sense of job security & $12.5 \%$ \\
\hline Skill formation of employees & $14.1 \%$ \\
\hline $\begin{array}{l}\text { Provide workplace that allows employees to demonstrate their capabilities, and } \\
\text { to pursue fulfilling work }\end{array}$ & $37.5 \%$ \\
\hline Concern for customers & $37.5 \%$ \\
\hline Commitment to high quality product & $35.9 \%$ \\
\hline Commitment to higher technology & $29.7 \%$ \\
\hline Concern for growth of firm, corporate group & $15.6 \%$ \\
\hline Concern for performance (including stability) & $9.4 \%$ \\
\hline Concern for environment & $17.2 \%$ \\
\hline Concern for local community & $10.9 \%$ \\
\hline
\end{tabular}

\begin{tabular}{|l|c|}
\hline \multicolumn{2}{|c|}{ Panel B: Norms and Behavioral Standards } \\
\hline Conscientiousness and cordiality on the job & $31.3 \%$ \\
\hline Innovation and originality & $45.3 \%$ \\
\hline Rise to challenges, aggressiveness & $18.8 \%$ \\
\hline Cooperation & $10.9 \%$ \\
\hline To live together with neighbors in harmony & $9.4 \%$ \\
\hline Fairness and transparency & $6.3 \%$ \\
\hline
\end{tabular}

The table shows the content of mission statements of 64 strong-culture firms, and the percentages of these firms which refer to these particular values, objectives, norms, etc. in their mission statements. 
Table 3 Descriptive Statistics

\begin{tabular}{|c|c|c|c|c|}
\hline & $\begin{array}{c}\text { Total } \\
\text { Sample } \\
\end{array}$ & $\begin{array}{c}\text { Strong Culture } \\
\text { Firms } \\
\end{array}$ & $\begin{array}{l}\text { Weak Culture } \\
\text { Firms } \\
\end{array}$ & Difference \\
\hline $\begin{array}{l}E M P \\
\text { (years) }\end{array}$ & $\begin{array}{l}15.95 \\
{[3.73]}\end{array}$ & $\begin{array}{l}16.35 \\
{[3.35]}\end{array}$ & $\begin{array}{l}15.56 \\
{[4.03]}\end{array}$ & $\begin{array}{l}0.79 \text { *** } \\
(0.000)\end{array}$ \\
\hline $\begin{array}{c}\text { INSIDER } \\
(\%)\end{array}$ & $\begin{array}{c}90.25 \\
{[11.61]}\end{array}$ & $\begin{array}{l}92.60 \\
{[8.85]}\end{array}$ & $\begin{array}{c}87.89 \\
{[13.43]}\end{array}$ & $\begin{array}{l}4.71 \text { *** } \\
(0.000)\end{array}$ \\
\hline $\begin{array}{c}D E B T \\
(\%)\end{array}$ & $\begin{array}{c}62.85 \\
{[18.63]}\end{array}$ & $\begin{array}{c}63.26 \\
{[16.32]}\end{array}$ & $\begin{array}{c}62.43 \\
{[20.69]}\end{array}$ & $\begin{array}{c}0.83 \\
(0.367)\end{array}$ \\
\hline $\begin{array}{c}\text { INTERLOCK } \\
\text { (\%) }\end{array}$ & $\begin{array}{c}26.25 \\
{[11.11]}\end{array}$ & $\begin{array}{l}28.91 \\
{[9.65]}\end{array}$ & $\begin{array}{c}23.59 \\
{[11.82]}\end{array}$ & $\begin{array}{l}5.32 \text { *** } \\
(0.000)\end{array}$ \\
\hline $\begin{array}{c}\ln T A \\
\text { (million yen) }\end{array}$ & $\begin{array}{l}12.56 \\
{[1.31]}\end{array}$ & $\begin{array}{l}12.92 \\
{[1.21]}\end{array}$ & $\begin{array}{l}12.20 \\
{[1.32]}\end{array}$ & $\begin{array}{l}0.71 \text { *** } \\
(0.000)\end{array}$ \\
\hline $\begin{array}{l}A G E \\
\text { (years) }\end{array}$ & $\begin{array}{c}57.31 \\
{[17.25]}\end{array}$ & $\begin{array}{c}58.72 \\
{[16.57]}\end{array}$ & $\begin{array}{c}55.90 \\
{[17.79]}\end{array}$ & $\begin{array}{l}2.82 \text { *** } \\
(0.001)\end{array}$ \\
\hline $\begin{array}{r}R O A \\
(\%)\end{array}$ & $\begin{array}{c}3.13 \\
{[2.93]}\end{array}$ & $\begin{array}{c}3.26 \\
{[2.74]}\end{array}$ & $\begin{array}{c}3.00 \\
{[3.10]}\end{array}$ & $\begin{array}{c}0.26 * \\
(0.072)\end{array}$ \\
\hline МКТВК & $\begin{array}{c}1.50 \\
{[0.63]}\end{array}$ & $\begin{array}{c}1.48 \\
{[0.53]}\end{array}$ & $\begin{array}{c}1.53 \\
{[0.73]}\end{array}$ & $\begin{array}{l}-0.04 \\
(0.115)\end{array}$ \\
\hline $\begin{array}{c}\text { PARENT } \\
\text { (\%) }\end{array}$ & $\begin{array}{c}7.65 \\
{[15.27]}\end{array}$ & $\begin{array}{c}3.94 \\
{[10.56]}\end{array}$ & $\begin{array}{c}11.36 \\
{[18.10]}\end{array}$ & $\begin{array}{l}-7.42 \text { *** } \\
(0.000)\end{array}$ \\
\hline $\begin{array}{c}\text { FOREIGN } \\
(\%)\end{array}$ & $\begin{array}{c}7.34 \\
{[7.57]}\end{array}$ & $\begin{array}{c}8.30 \\
{[8.02]}\end{array}$ & $\begin{array}{c}6.38 \\
{[6.97]}\end{array}$ & $\begin{array}{l}1.92 \text { *** } \\
(0.000)\end{array}$ \\
\hline Sample Size & 1628 & 814 & 814 & \\
\hline
\end{tabular}

Figures in the Total Sample, Strong Culture Firms, and Weak Culture Firms columns are sample means. Standard deviations are in brackets.

Figures in the Difference column are the differences in means between the strong culture sample and the weak culture sample. $* * *, * *, *$ indicate that the difference is significant at $1,5,10 \%$ level, respectively. $\mathrm{P}$-values are in parentheses. 
Table 4 Corporte Culture and Employment Policy

\begin{tabular}{|c|c|c|c|c|}
\hline & \multicolumn{4}{|c|}{$\overline{\text { Dependent variables: } E M P}$} \\
\hline & $(1-1)$ & $(1-1)^{\prime}$ & $(1-2)$ & $(1-2)^{\prime}$ \\
\hline Intercept & $\begin{array}{l}11.39 * * * \\
(0.000)\end{array}$ & $\begin{array}{l}12.56 * * * \\
(0.000)\end{array}$ & $\begin{array}{l}11.43 * * * \\
(0.000)\end{array}$ & $\begin{array}{l}12.67 * * * \\
(0.000)\end{array}$ \\
\hline CULTURE & $\begin{array}{l}0.593 * * * \\
(0.001)\end{array}$ & $\begin{array}{l}0.648 * * * \\
(0.000)\end{array}$ & $\begin{array}{r}0.268 \\
(0.143)\end{array}$ & $\begin{array}{r}0.247 \\
(0.177)\end{array}$ \\
\hline TOP $\times C U L T U R E$ & & & $\begin{array}{l}0.930 \text { *** } \\
(0.001)\end{array}$ & $\begin{array}{l}0.980 * * * \\
(0.001)\end{array}$ \\
\hline TRAIN $\times$ CULTURE & & & $\begin{array}{r}0.284 \\
(0.281)\end{array}$ & $\begin{array}{c}0.457 * \\
(0.083)\end{array}$ \\
\hline $\ln T A$ & $\begin{array}{r}0.097 \\
(0.115)\end{array}$ & $\begin{array}{r}0.083 \\
(0.180)\end{array}$ & $\begin{array}{r}0.099 \\
(0.127)\end{array}$ & $\begin{array}{r}0.078 \\
(0.233)\end{array}$ \\
\hline$A G E$ & $\begin{array}{l}0.045 * * * \\
(0.000)\end{array}$ & $\begin{array}{l}0.042 \text { *** } \\
(0.000)\end{array}$ & $\begin{array}{l}0.043 \text { *** } \\
(0.000)\end{array}$ & $\begin{array}{l}0.040 * * * \\
(0.000)\end{array}$ \\
\hline$R O A$ & & $\begin{array}{l}-0.167 * * * \\
(0.000)\end{array}$ & & $\begin{array}{l}-0.185 * * * \\
(0.000)\end{array}$ \\
\hline MKTBK & & $\begin{array}{r}-0.134 \\
(0.462)\end{array}$ & & $\begin{array}{r}-0.073 \\
(0.689)\end{array}$ \\
\hline Year Dummy & Yes & Yes & Yes & Yes \\
\hline $\mathrm{R}^{2}$ & 0.088 & 0.107 & 0.095 & 0.116 \\
\hline Sample Size & 1628 & 1628 & 1628 & 1628 \\
\hline
\end{tabular}

$* * *, * *$, and * indicate that the coefficient is significant at the $1 \%, 5 \%, 10 \%$, level, respectively.

P-values, calculated by White's (1980) heteroskedastic-consisitent standard errors, are in parentheses. 
Table 5 Corporate Culture and Board Sturucture

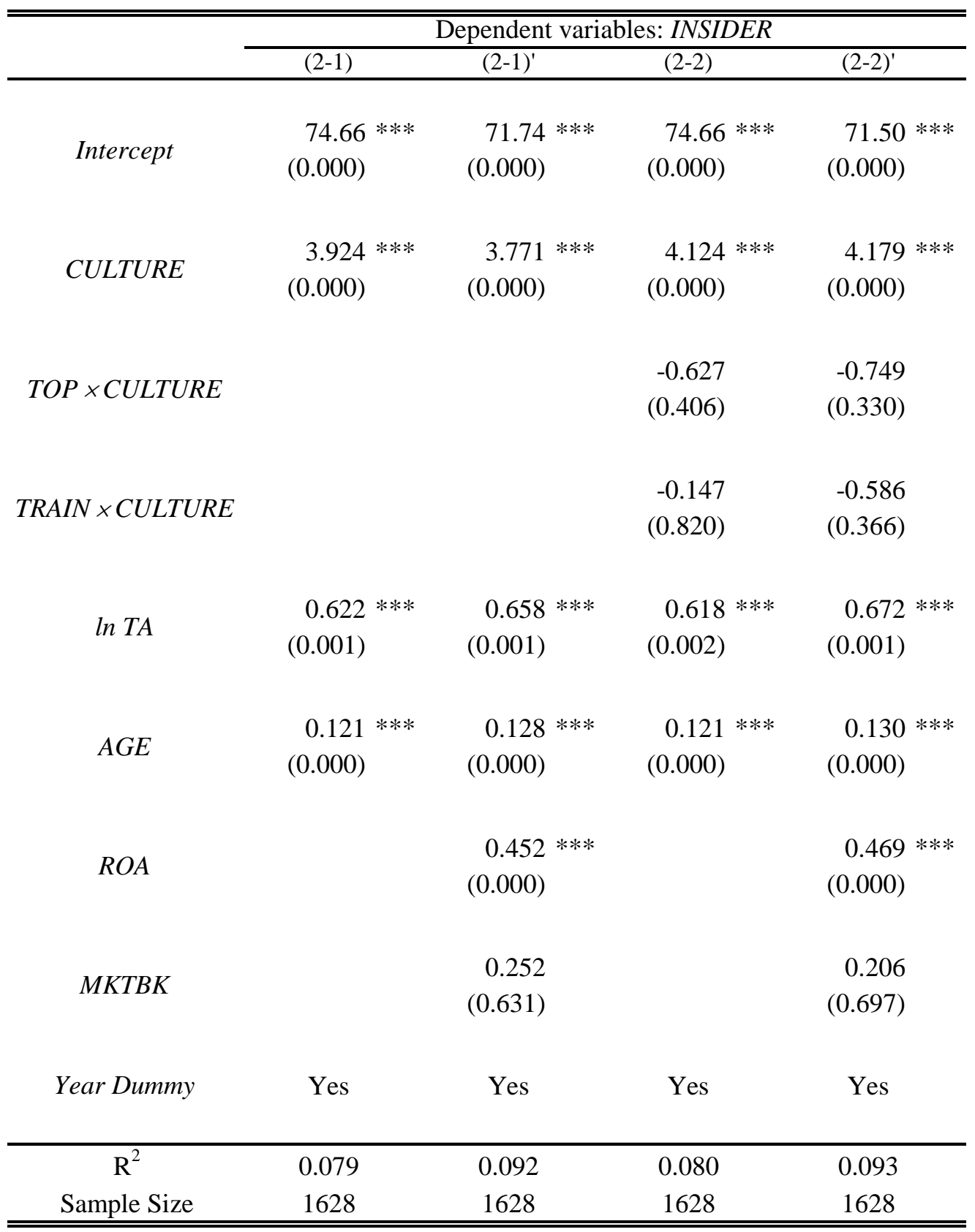

$* * *, * *$, and * indicate that the coefficient is significant at the $1 \%, 5 \%, 10 \%$, level , respectively.

P-values, calculated by White's (1980) heteroskedastic-consisitent standard errors, are in parentheses. 
Table 6 Corporate Culture and Capital Structure

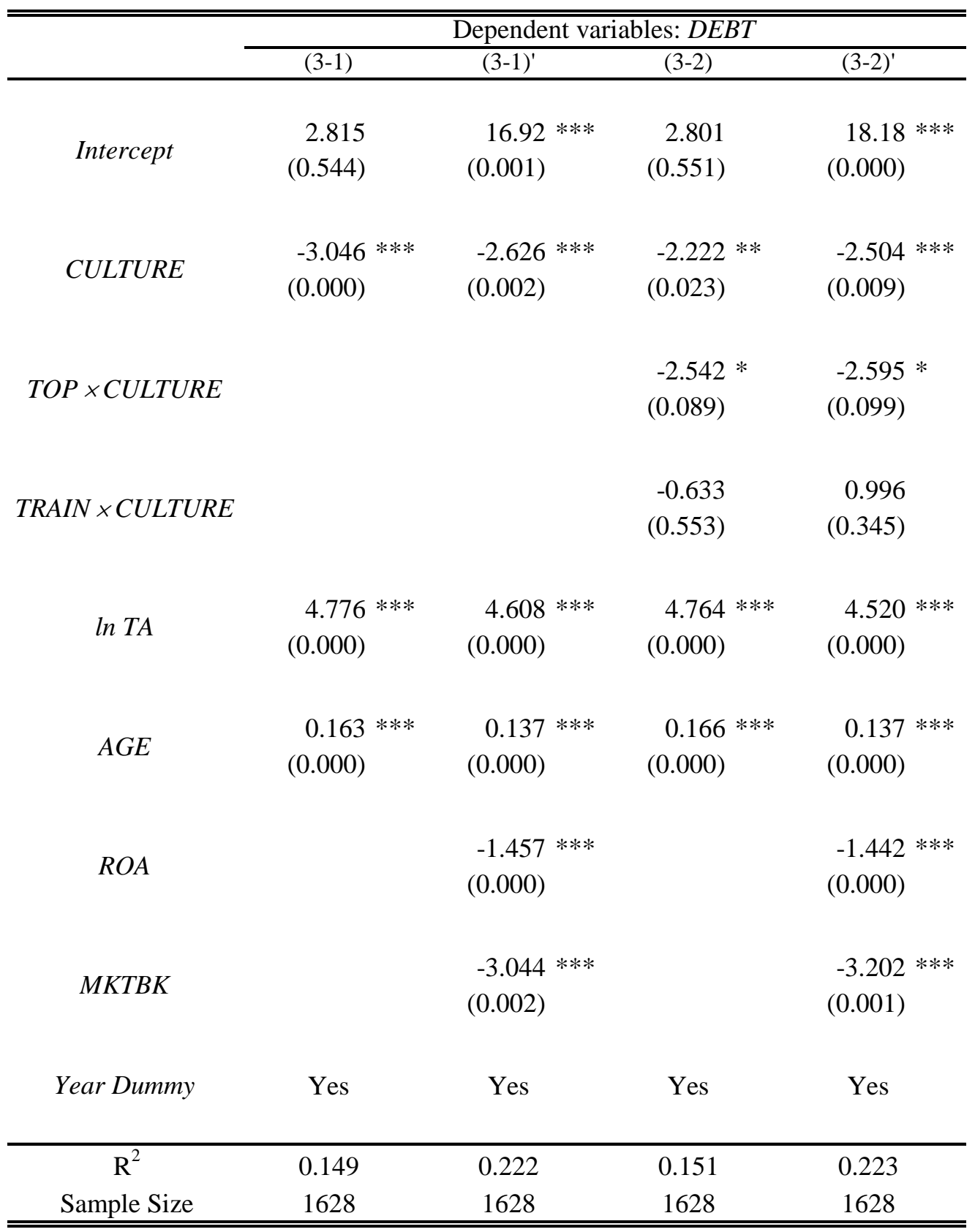

$* * *, * *$, and * indicate that the coefficient is significant at the $1 \%, 5 \%, 10 \%$, level , respectively.

P-values, calculated by White's (1980) heteroskedastic-consisitent standard errors, are in parentheses. 
Table 7 Corporate Culture and Interlocking Shareholdings

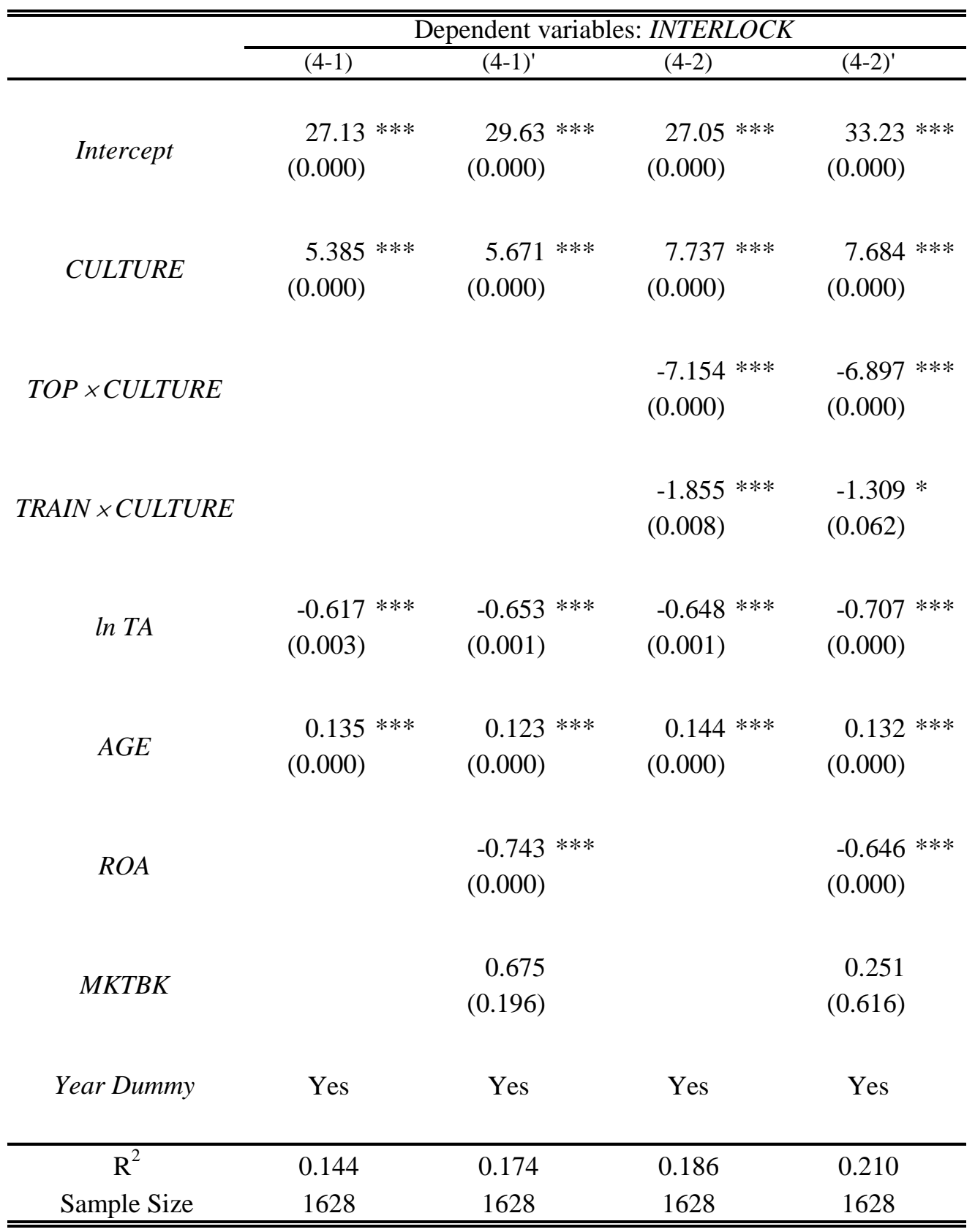

$* * *, * *$, and * indicate that the coefficient is significant at the $1 \%, 5 \%, 10 \%$, level, respectively.

P-values, calculated by White's (1980) heteroskedastic-consisitent standard errors, are in parentheses. 
Table 8 Corporate Culture and Profitability

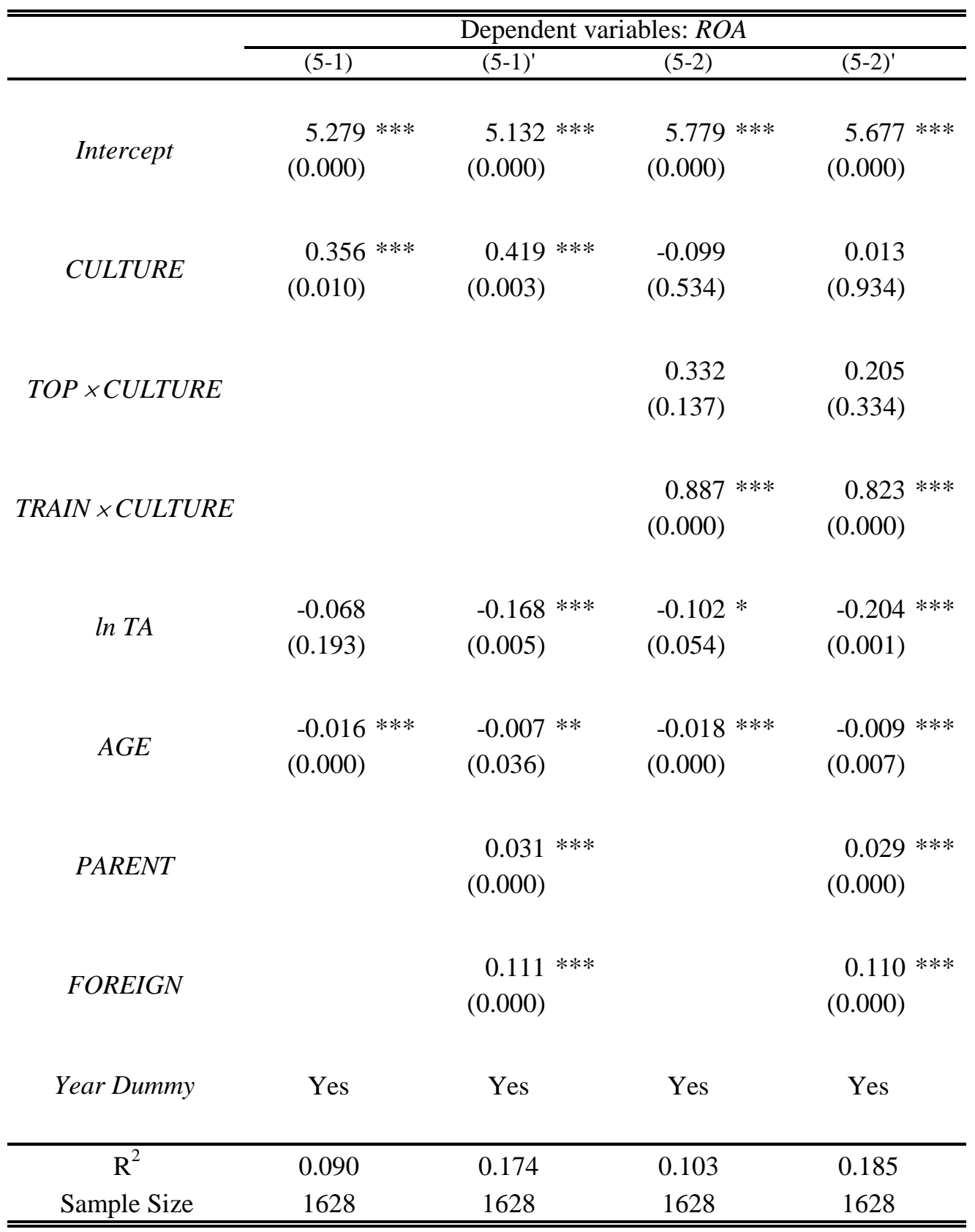

$* * *, * *$, and * indicate that the coefficient is significant at the $1 \%, 5 \%, 10 \%$, level , respectively.

P-values, calculated by White's (1980) heteroskedastic-consisitent standard errors, are in parentheses. 